\title{
Belgeo
}

Revue belge de géographie

\section{Learning from Brussels. An irreductive approach to architectural and urban problématiques?}

Leren van Brussel. Een irreductieve benadering van architecturale en stedelijke problématiques?

\section{Isabelle Doucet}

\section{(2) OpenEdition}

\section{Journals}

Electronic version

URL: http://journals.openedition.org/belgeo/7092

DOI: $10.4000 /$ belgeo.7092

ISSN: 2294-9135

\section{Publisher:}

National Committee of Geography of Belgium, Société Royale Belge de Géographie

Printed version

Date of publication: 30 June 2011

Number of pages: $29-40$

ISSN: 1377-2368

\section{Electronic reference}

Isabelle Doucet, «Learning from Brussels. An irreductive approach to architectural and urban problématiques? », Belgeo [Online], 1-2 | 2011, Online since 04 December 2012, connection on 01 May 2019. URL : http://journals.openedition.org/belgeo/7092 ; DOI : 10.4000/belgeo.7092

This text was automatically generated on 1 May 2019.

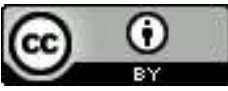

Belgeo est mis à disposition selon les termes de la licence Creative Commons Attribution 4.0 International. 


\title{
Learning from Brussels. An irreductive approach to architectural and urban problématiques?
}

\author{
Leren van Brussel. Een irreductieve benadering van architecturale en stedelijke \\ problématiques?
}

Isabelle Doucet

\section{Introduction}

1 This article starts from the distinction made by Belgian philosopher Isabelle Stengers between le choix de la complexité and le choix de la complication, and, in relation to cities, la ville complexe and la ville compliquée (Stengers, 2000). Stengers argues that, against the reality of cities, we continue making the choix de la complication rather than daring to choose for complexité. I would like to link such argument with architects' longstanding attempt to "solve" the city, and, in order to do so, their enhancement of the choix de la complication. The main aim of this article is to call for a methodological approach to cities that allows complexity. It will zoom in on the recent exhibition "Building for Brussels. Architecture and Urban Transformation in Europe" (9 October until 28 November 2010, BOZAR, Centre of Fine Arts in Brussels), and argue that it is a showcase of how architects struggle to adopt such approach.

2 Isabelle Stengers has argued that modern urban planners opted - largely for practical reasons - for the choix de la complication and, thus, explicitly chose against complexity. In contrast to complex entities, being continuously modified and negotiated, human societies have developed rules and conventions that allow to stabilise entities, in order to make them workable (Stengers, 2000) ${ }^{1}$. It is thus a practical measure that transforms the "se faisant" (in the making) into "tout fait" (made) (Stengers, 2000). As such, Stengers 
argues that "La Ville Moderne", with its obsession with order, rationality and its hatred of conflict and disorder, was a downright example of "lutter contre la complexité par la complication" (Stengers, 2000). This choice can be traced back to the $19^{\text {th }}$ Century hygienist approach to the city, most notably in line with Baron Haussmann's transformation of Paris, and, in Brussels, effectuated by the covering of the River Senne, the creation of grand urban boulevards, and iconic architectural works such as the Court of Justice. One can argue that demolition, as the ultimate modern way to "cleanse" the urban fabric, has now gone out of fashion, but that a complication-driven planning attitude has nevertheless survived (see further). Stengers indeed argues that we maintain the choice for "la ville compliquée" for it is homogeneous, legible from the outside, because it allows us to dissect its different components ; for it is organised, and functional. Instead, Stengers suggests doing something far more risky, namely to look at cities as complex entities, as a city that learns: "la ville complexe" or "la ville qui apprend" (Stengers 2000). Such city is a city that is opaque from the outside, that is always more draft than finished product (in-the-making, learning, negotiated) : "une ville brouillone, incertaine, pleine de palabres et de négociations, et donc relativement opaque par rapport à l'extérieur" (Stengers, 2000).

This calls for a research approach within architectural and urban studies that no longer focuses on the theories, ideas and ideologies that often (even if implicitly) surround urban and architectural questions. Instead it argues to study how those are practiced, and, thus, how they get materialised, consolidated, or corrupted over time, through the messiness of spatial practice. Such approach implies to deploy theories and questions about cities and the (production of the) built environment in a pragmatist way, namely in terms of their effects and concrete consequences - whether they make a difference (James, 1995 [1907]). But it also implies the acceptance that urban and architectural questions cannot be unravelled straightforwardly and reduced into parts - in reference to Irreductions (Latour, 1988 [1984], pp. 151-236). Instead, it suggests looking at cities in terms of an imbroglio - "an extremely confused, complicated, or embarrassing situation" (Oxford On-line Dictionaries) - or : a complex knot of stakes, ideas, actors, and practices².

\section{The search for an irreductive modus operandi}

When approaching the architectural and urban condition in a pragmatist, irreductive manner, one resists the temptation to deploy a set of externally produced categories, theories or ideologies as frameworks through which the world can be understood. Instead one starts from the situation itself, from the specificity of that situation. It is not just about looking at how architecture and urban production are practised, but how they are practised in all their complexities and intricacies. Such methodological urge requires both more complex accounts of objects (whether it is a city, a building, or architecture production in Brussels) and an appropriate modus operandi for making such accounts.

Relational philosophies and theories sprouting from Philosophy of Science, Science and Technology Studies, and Object-centred Anthropology (e.g. Appadurai, 1988 [1986]) have meanwhile developed numerous metaphors for depicting more complex accounts of objects. Such accounts no longer distinguish between the technical or engineering aspect of objects and their "human dimension", between human and non-human agencies, between indisputable facts and more subjective values, and between substance and network. Objects, or better "things" or "issues", are no longer approached as matters of 
fact, but as "matters of concern" (Latour, 2004; 2005). Objects are approached as "hybrids", "quasi-objects" (Serres, 1982), "objects-in-flight" (Latour and Yaneva, 2009), or, as "fluid objects" (Mol and De Laet, 2000 ; Law and Mol, 2005).

6 All such metaphors share the conviction that we are not dealing with nicely confined objects that can be disconnected from their multiple entanglements with the real, but with "things" that are composed of a complex and varied set of threads and knots that are not immediately distinguishable. Objects are thus considered as being "situated" in multiple networks; only accessible through "situated and embodied knowledges" (Haraway, 1991, p.191). The only way to understand and evaluate an object is by understanding all of its entanglements. Moreover, because an object's entanglements or "alliances" with the real, change over time (over the course of an object's life), the boundaries of an object are never "fixed". Its boundaries change over time, which determines the fluidity of objects ${ }^{3}$. Throughout its life, a thing takes part in continuous negotiations and alliances - "trials of strength, of weakness" (Latour, 1988, p. 158) which makes it impossible to pin it down, to fix its boundaries and to read/evaluate it "for once and for all". Only temporary fixations are possible, because in the endless game of negotiation with the real (the thing coping with its "situatedness"), it costs too much to freeze negotiation, to establish and maintain shapes, permanence and durability (Latour, 1988). Objects, therefore, no matter how rigid they may appear (such as buildings), cannot be frozen by our gaze for once and for all. Bruno Latour, therefore, asks for (architectural) objects : "What do we show ?" (Latour, 2004b) : do we show the finished object disconnected from the numerous assemblages that have not only made it, but that also keep it together? Or do we show these networks of fabrication, the building's situatedness? In other words, Latour wonders why we show modernism's "bald objects" while we are increasingly dealing with "dishevelled, hairy, networky 'things"“, with entangled knots that can only be understood through their networks and assemblages (Latour, 2004b). It is what Jeremy Till has called, in relation to architecture, the allowance of "uncertainty in place of purity" and the acceptance of "messiness" and insecurity as part of the work of architecture (Till, 2006) ${ }^{4}$. One way to understand (and, thus, evaluate) such entangled objects or imbroglios is by unravelling their different components and trajectories. By unravelling how an object (a building, a design project, an idea or discourse) has been practised in both space and time, one can learn how it is situated and how such practising has transformed, neutralised, consolidated, or perverted its initial characteristics or intentions. It is about unravelling or "unmasking" the different practices that compose a city, situation, or object. Such methodological approach explicitly counters the belief that a situation can be grasped in one overview, one plan, and thus, it erases the possibility of all-encompassing solutions for a specific situation (e.g. blueprints). As Bruno Latour has shown in his study of Paris - Paris Ville Invisible - a city cannot be grasped through the all-encompassing view of the panorama ; we can only grasp a city through an oligoptic view : based on partial accounts of the different Parises (Latour and Hermant, 1998).

7 In architecture discourse, this seems, today, a rather obvious observation. The belief in blueprints and all-encompassing plans has since long diminished. Late-modernist critiques and post-modern architectural and urban visions have explicitly opposed the modernist obsession with the orchestration of the user and the belief that the city can be "cured" from its non-modern diseases. And yet, the projective nature of architecture - it always has to imagine, realise, and, thus guarantee a project in practice - has left largely 
unresolved the tensions between orchestration and contingency ; between full control (as to "guarantee" impact) and an openness towards what is happening on the ground (letting go, allowing the user to engage); and between the processing of architecture's engagement with the world through either theory or practice. As Hilde Heynen has argued in relation to the early $20^{\text {th }}$ Century architectural avant-garde (and in particular Bauhaus), it is precisely this projective nature of architecture, namely, its desire, obligation, and opportunity to intervene in the world in concrete manners, that has often troubled architecture's critical engagement with the world (Heynen, 1999). In order to "get things done", architects have for long struggled to safeguard their critical positions while "testing" these positions in practice (through realised buildings and projects). This balancing has often been associated with "compromising" the initial aims, ideas, and critical takes. Not surprisingly, the "anything goes" mood suggested by the multiple postmodernisms in architecture; the failure "in practice" of many participatory, communitydriven, and "good intentions" architectures (e.g. Community Architecture and New Urbanism); and the mounting distrust of (critical) theory's effectiveness in concrete, practical circumstances, has recently generated a debate turning towards the "agency" of architecture. "Agency" is no longer understood in opposition to structure but in terms of the complex entanglement of architecture with the world. Influenced by recent developments in the social sciences (and most notably the work of Bruno Latour, Albena Yaneva, Sophie Houdaert, and Actor-Network-Theory) ${ }^{6}$, agency has come to be seen as a promising theoretical and analytical tool for architecture, not the least because it allows to take into account both the actions of individuals (e.g. architects, users) aiming to produce effect and the fact that architects are always "at the service" of a client ${ }^{7}$. Such interest in agency not surprisingly collides with a renewed interest in practice (and not theory) as the ideal locus to evaluate the impact of architecture.

\section{"Building for Brussels" and le choix de la complication}

8 Charles Jencks argued that modern architecture had officially died in 1972, at a very precise date and time, namely on "July 15, 1972 at 3.32 pm (or thereabouts) when the infamous Pruitt-Igoe scheme [...][a celebrated, award-winning modernist housing complex] were given the final coup de grace by dynamite" (Jencks, 1991 [1977], p. 21). There are, however, many instances that indicate that, despite the numerous antimodern claims of post-modernism, a modern approach to space - in terms of control and orchestration - has not entirely given in. 19 November 2010, somewhere between 1 and 3 $\mathrm{pm}$, was one of those instances where one realised that, indeed, modern techniques of complication are fresh and alive. On November 19, I visited the Building for Brussels exhibition at the Brussels Centre for Fine Arts $^{8}$, which I perceived as unsettling : not for its lack of quality, nor for it produced provocation or shock - in fact, the exhibition was very well made and its content was painfully consensual after all - but because it made so dauntlessly the choix de la complication precisely when it had the unique opportunity to chose for complexité.

9 The exhibition's central question is why "a metropolis like Brussels [should] invest in architecture and urban planning at a time when it is faced with vast social challenges" (Declerck, 2010, p. 8). And it is quite bold in answering that question straight away : "[Yes, indeed] Building for Brussels argues that high-quality architecture and urban design projects can offer an answer to the city's metropolitan challenges" (Declerck, 2010, p. 8). 
With "social challenges" it then refers to problems as wide as they are structural, such as : population growth, shortage of schools and public infrastructure, unemployment, traffic congestion, and conflicts between Brussels' supranational functioning and living quality (Declerck, 2010, p. 9). So what have we got here: an architecture that can solve the world? So it seems. And on five levels at the same time: demography, mobility, urban economy, public facilities and new districts (organised in five rooms with project models and a video with interviews with Brussels stakeholders and local and international architects and theorists). But this is only one of many indications that this exhibition has made the choix de la complication.

10 Firstly, the exhibition proposes a learning process that is typically part of "la ville compliquée", namely a learning process that is selective (even opportunistic) and that doesn't allow to draw lessons from Brussels' complexity - the memory it creates is only passive.

That the learning process is selective is first of all shown by the very starting point of the exhibition : suggesting solutions for Brussels by looking at other geographical cases and "best practices". Such case-based approach may suggest learning: learning through external referents drawn from contexts that are supposedly comparable to Brussels. However, it is not because most inner cities have suffered from the flight of the middle classes, or because cities have shown the so-called success stories of regenerating vast post-industrial sites, that (firstly) the same successes can be expected in Brussels, and (secondly) that such aspirations are to be uncritically accepted as desirable. The exhibition suggests that the urban regeneration as we have seen it emerging over the past two or three decades, has been successful, and yet it makes total abstraction of the numerous side-effects of such processes that have been extensively studied gentrification, social exclusion and displacement (e.g. the writings of, amongst others, David Harvey, Neil Smith, and Erik Swyngedouw) ${ }^{9}$. As such, it presents a hopeful yet opportunistic and unrealistic plan. For example, the VoltaMitte housing development (Christ \& Gantenbein) in Basel-Nord may very well be considered a successful architectural gesture to insert new middle-class housing in a working class neighbourhood. However, if we are to believe the project architect (interviewed in one of the exhibition films), this success can be brought back to the aesthetic and formal integration of the architecture in the neighbourhood, namely : unpretentious, respectful and modest. No mention is made whatsoever of the broader mechanisms such projects can trigger : if successful, it may lead to the total gentrification of the area and the social displacement of the original working class population. Perhaps it is too soon to measure such effects (the project is finished only recently)? In that case, it is dangerous to use it as a case in the first place. Perhaps, and this is likely, it is simply not aware of, or not concerned with such effects. If that's the case, we should of course ask ourselves whether it is a good idea to leave the "curing" of the city in the hands of architects. Another example confirms this. The exhibition categorises the youth education centre and metal workshop Dynamo (Zurich, Phalt Architects) as a case for "urban economy" for it fights unemployment by providing education and for it does not hide such activity but locates the workshop in the centre of a public space (De Bruyn and Declerck, 2010, p. 34). But once again, the complete gentrification of even the most deprived areas of our cities seems to be the leitmotiv : in the exhibition film, one of the architects proudly declares how this was once a downward area and has now become the "place to be" (in the summer : "full of terraces"). 

Capital of Europe (BOZAR, 2007, also curated by Joachim Declerck, this time with PierVittorio Aureli and The Berlage Institute - see also Doucet, 2007) the exhibition refuses to provide an "active memory" of its own learning process. Despite its literal "learning" from international cases, it makes abstraction of the wealthy history that has nurtured the local architectural emancipation process that this exhibition, unmistakably, aims to complete : "in order to lead the city into the $21^{\text {st }}$ Century" (Declerck, 2010, p. 8). A Vision for Brussels likewise celebrated a "myth of the new" that made no mention of numerous earlier practices that had paved the way since the mid-1990s : Brussels urban activism of Citymined, Cinema Nova, MAPRAC, Platforme Flagey, Vacant City, A Moving City, and many more. As such it denies two aspects that are very specific to the Brussels architectural and urban emancipation. Namely, its "concerned" character - a more critical interpretation of architectural emancipation and neo-liberal stardom - and the fact that this emancipation is, in Brussels, a "collective" action that cannot be brought back to one single gesture, vision, or plan. In other words, its use of external cases (no matter how instructive they may be), its intellectual tabula rasa, and celebration of the myth of the new, leads Building for Brussels to deny the specificity of Brussels as a learning practice. Isabelle Stengers has argued for the creation of an "active memory" that allows us to discover how "solutions that we might have considered promising, turn out to be failures, deformations, or perversions" (Stengers, 2005, p. 998). An "Active memory" allows, thus, to keep track of and retrace our decisions as we make them in practice. It considers practice as a key context for it is, in practice, that one is confronted with the consequences of one's actions (Stengers, 2005, p. 997). Likewise, also Bruno Latour emphasised the importance to keep careful track of our learning processes throughout experiments: because only by making available the traces, and thus the history of our learning, can we allow one to reconsider the chosen steps, to ask some of the questions anew and, thus, to allow for different possibilities (Latour, 2004c). Compared to such "Ecology of Practice" (Stengers, 2005b) and "Political Ecology" (Latour, 2004c), Building for Brussels appears disquietingly "modern" in its approach.

This brings us to a second reason why I believe the project has chosen for the ville compliquée and not the complex city. The whole plan for Brussels' architecture seems to be one of "catching up" and of finally making progress after decades of imprisonment in the "fear of the new", a lack of ambition, and reluctance to bold urban visions. This fear can, of course, be brought back to the infamous Brussels' "urban trauma", with which one refers to the suffering of the Brussels population under the numerous modernisation read : demolition and speculation - works delivered by modern planners and architects, from the vast "Haussmannian" transformation of $19^{\text {th }}$ Century Brussels under le roi urbaniste, over the modernisation fever of the golden decades with Expo 58 and the Manhattan Plan, up to the housing of the European Institutions. If we add to this "urban trauma" the complexity and opaqueness of Brussels politics - and the consequent sensation of undemocratic decision making - one can understand the importance of bottom-up, participatory development and the suspicion vis-à-vis top-down, innovative, and structural interventions. This has, in addition, generated an architectural culture that has for long been strongly dominated by a traditionalist view on the city, wary of an excessively creative and innovative architecture-for-architects (rather than for citizens) ${ }^{10}$ 
14 As a consequence, when, under the spell of the neo-liberal dream, architecture had become the tool par excellence to catapult cities from post-industrial depression into creative and tourist Walhalla's, and to place even the remotest of places on the global capitalist map, Brussels remained remarkably silent in terms of iconic architecture and large-scale urban regeneration schemes ${ }^{11}$. In the videos shown in the exhibition, it is, thus, repeatedly argued that Brussels has to catch up, and that, precisely because Brussels is so dramatically behind, iconic architecture can still have its effect ${ }^{12}$. Such longing for innovative architecture is of course understandable after decades of architecture oppression, but it should not legitimise a blind acceptance of architecture as branding now that so many of the side-effects have become apparent. Nevertheless, as in the 2007 A Vision for Brussels, it is once again architecture that is believed to be the ideal tool for "solving" or "rescuing" the city. In A Vision for Brussels it was the ambiguous status of the abstract-yet-realistic monumental architectural schemes offered by the "concrete plan for Brussels" and the actualisation of monumental architectural "form" that was believed to offer the ultimate way to solve urban questions (Doucet, 2007, p. 97 ; p. 102). In Building for Brussels it is the magic of best practices and international cases that can seemingly tackle all of Brussels' problems. In both cases it is a strong disciplinary belief in the all-encompassing transformational force of architecture that guides such promises. In a promotional video, Joachim Declerck confirms, quite remarkably, these high expectations of architecture :

15 People live in cities. People, of course, have, um, a lot of means, few means ; have work, or no work. But they always live in a certain space, so you cannot deny that the problem or their chances or their development depends always also on the place where they live, where they work, and the transport in between. Thus, in that sense is the architecture of all these places - of the dwelling, workplace and transport - something that can ameliorate the quality of their lives. And that is what, in five rooms, is explored in this exhibition $^{13}[\ldots]$

16 Now, how much more blatantly can one not make the choix de la complexité? In addition, the current celebration of "one future, one vision" in political (and professional) circles $^{14}$, infused by strong ideas, bold urban visions, and daring architecture, risks to deny the possibilities that, so typically in Brussels, reside in the numerous interstices and cracks of the urban system. Blinded by the urge for grand solutions, it neglects to decipher the hidden potentials that are already embedded in the fabric, awaiting articulation.

Within the Brussels context, one can think of the PleinOpenAir festival, a series of openair film screenings, organised by Citymined and Cinema Nova since 1997, which attempted to generate critical public awareness of buildings threatened by demolition, or abandoned sites in need of development. Over the years, this festival has managed to both trigger new debates and ally with, and as such reinforce, existing debates ${ }^{15}$. Collectives such as Cinema Nova, Citymined, but also Recyclart, have demonstrated the importance to be sensitive to the interstices, but also to approach architectural and urban production simultaneously architecturally, socially, economically, and culturally. In addition, they stressed the importance to operate as urban laboratories integrating all sorts of inputs and knowledges, and processing them through experimentation. Such collectives indicate an approach that avoids a too abstract solution from above (no matter how brilliant that solution may appear), without, however, falling into the trap of naïve, but unproductive opposition. 
18 For example, the three-day workshop MAPRAC, organised by, amongst others, Citymined, in $2004^{16}$, involved a variety of "experts" including architects, urban developers, historians, sociologists, geographers, residents, and artists, and was divided into thematic workshops on architecture, procedures, mobility, urbanism, and sociology. This hybrid format allowed the fusion of theoretical and practical insights; of academics, practitioners, and inhabitants; and of the analysis of existing problems as well as the formulation of a vision for the future. Laboratories such as MAPRAC are instructive for understanding the possible leverage of situated knowledges ${ }^{17}$. Like many other urban activist initiatives, the real impact of MAPRAC can only be measured by also taking into account its indirect and delayed effects. It may not have had a concrete impact on the development of the site itself but its insistence on an inter-disciplinary urban debate has influenced urban policies. In 2006, after the site had been sold to private developer Breevast NV, it was the first site to be allocated a Schéma Directeur : a new, more integrated and participatory development tool for "Sites of Regional Importance". Also, MAPRAC would set a new standard of ambition for Brussels' (urban) activism. Whereas, before, activism had been rather modest in scale and fragmented in nature, MAPRAC showed the potential of collective, large-scale action.

Also Recyclart's active contributions to the debates on architecture and the city, show their sensitivity to what's already embedded in the Brussels Situation. With public space projects such as the Bruegel Square and the Skatepark Ursulines, and with its support for the Parckdesign competition, Recyclart refreshed the debate on public space design and, in particular, it challenged embellissement as Brussels' ideal urban design approach ${ }^{18}$. Likewise, the creation of the Institut Bruxellois d'Architecture/Brussels Architectuur Instituut (IBAI) may have been inspired by the Vlaams Architectuur Instituut (VAI); it nevertheless offers, from the outset, a much more interdisciplinary, cultural and urban debate on architecture. In terms of its programming, organisation, and audience, IBAI is more informal than the VAI. It is entangled with the Brussels situation and the activist legacy of Hôtel Central and Brussels 2000, while it is equally inspired by international expertise. It has, in that sense, attempted to achieve scope and impact without betraying its activist roots.

20 As happened to many other urban activist collectives in Brussels, Recyclart's Institut Bruxellois d'architecture (IBAI) has not opted to "boom", to become a powerful architecture culture institute such as the VAI, but instead has kept questions of institutionalisation, professionalisation, and growth open to negotiation. Also in its realised projects - Bruegel Square, Skatepark Ursulines, Parckdesign - Recyclart aspires hybrids of contemporary design, urban culture and citizen participation ${ }^{19}$. This search for a balance between oppositional critique/activism and impact/ scope can be found within many activist collectives throughout the 2000s, and in particular those that would benefit from more structural support since Brussels 2000. Much of the urban activism forced itself to confront a certain degree of "compliance" with the system (financial support, participation in official planning instruments), with a rethinking of its working formats, frameworks, and outputs, precisely in order to safeguard ideological independency as much as possible. Due to such continuous balancing, Brussels activism has remained a fragmented (though internally solidary) landscape of individual initiatives while having grown increasingly effective (e.g. Flagey) : they prefer to negotiate alliances according to shared (or complementary) interests rather than according to frameworks imposed from the outside. 
21 proclaims a typically "modern" project based on probability - as "calculated anticipation, authorised by the world as it is" - rather than possibility : by being attentive to what is lurking in the interstices (Stengers, 2002, p. 245). It is all about the mobilisation of cases and best practices, about the healing promises of architectural form and the cleansing march of progress, rather than about the stumbling, hesitant, learning processes that allow complex, conflicting and contradicting accounts ${ }^{20}$. We need, of course, to acknowledge that Brussels needs structural solutions - to tackle, amongst others, its sharp socio-spatial segregation, unemployment and poverty rates, and its chronic social housing crisis. However, the question remains whether an over-arching architectural gesture is ultimately the right tool to effectuate that.

perhaps too manifesto-like tone of this article is therefore to be interpreted as an effort to simply tone down the new tendency for yet another "once and for all" solution, a grand catching up that, without a single blink of hesitation, proposes to (once again!) cure Brussels : this time not from its modernisers, but from its traditionalists who, by clinging onto Brussels' urban trauma, continue to paralyse architecture production. Brussels may be a scarred city, a fragmented and complex one. But, to a certain extent, many cities are scarred, fragmented and complex. Thus, isn't it time we started working with rather than against such complexity? Isn't it time we gave up the ideological tabula rasa's with which Brussels has been overwhelmed all too often (whereas those are progressive or traditionalist) and to start adopting a more hesitant approach? What we are facing is the enormous task to rethink the "right to the city" amidst the assaults made by neo-liberal urban planning (Harvey, 2008), but at the same time we may have to start accepting that such recovery of the "right to the city" may no longer be achieved through oppositional techniques and frontal attacks. Instead, we may have to accept that what's at stake is the reading of our urban problematiques in terms of practices that cannot be "overthrown" for once and for all, no matter how brilliant our solutions may appear. If we accept the city as a learning process, we may have to start accepting that, whatever solutions we may develop, they may fail. And that the success of our actions can be measured by what we learned from our failures, and not by covering them all too well with the gleaming light of superficial, short-term victories. In that sense, what is needed is not per se a "solution" but an "indication of the ways in which existing realities may be changed" (James, 1995 [1907], p. 21). The pragmatist mood that clearly interlaces this article, may, in other words, not tell us where one should go; it is nevertheless preoccupied with the sense of our choices, desires and directions. Or, as Louis Menand observed, in relation to pragmatism's intentionality problem :

We wake up one morning and find ourselves in a new place, and then we build a ladder to explain how we got there. The pragmatist is the person who asks whether this is a good place to be. The nonpragmatist is the person who admires the ladder (Menand, p. xxxiv). 


\section{BIBLIOGRAPHY}

APPADURAI A. (ed.) (1988 [1986]), The Social Life of Things : Commodities in Cultural Perspective, Cambridge, Cambridge University Press.

BRENNER N. \& THEODORE N. (eds.) (2002), Spaces of Neoliberalism, Oxford, Blackwell.

CAIRNS S. (2009), "How do architects act on behalf of others? Modes of comportment and possibilities for action", Architecture research quarterly, 13, 2, pp. 105-108.

DE BRUYN J. \& DECLERCK J. (2010), Building for Brussels. Architecture and Urban Transformation in Europe, exhibition guide.

DECLERCK J. (2010), “Curatorial Statement”, in DE BRUYN J. \& DECLERCK J., Building for Brussels. Architecture and Urban Transformation in Europe, exhibition guide, pp. 8-9.

DOUCET I. (2007), “A Vision for Brussels : Fuel to the Urban Debate or, at Last, an End to the Brussels Trauma?", Footprint Journal, 1, Autumn 2007, pp. 97-105.

DOUCET I. (2008), "Planning in Search of Ground : Committed Muddling Through or a Critical View from Above ?", in MACIOCCO G. (ed.), The Territorial Future of the City, Berlin and Heidelberg, Springer Verlag, pp. 47-70.

DOUCET I. \& CUPERS K. (eds.) (2009), “Agency in Architecture : Reframing Criticality in Theory and Practice", Footprint Journal, 4, Spring 2009.

HARAWAY D. (1991), "Situated Knowledges : The Science Question in Feminism and the Privilege of Partial Perspective", in Simians, Cyborgs, and Women. The Reinvention of Nature, London, Free Association Books, pp. 183-201.

HARVEY D. (2008), “The Right to the City”, New Left Review, 53, Sept.-Oct., pp. 23-40.

HEYNEN H. (1999), Architecture and Modernity. A Critique, The MIT Press.

HOUDAERT S. \& MINATO C. (2009), Kuma Kengo : Une monographie décalée, Les Éditions Donner Lieu.

JAMES W. (1995 [1907]), “What Pragmatism Means”, in Pragmatism, New York, Dover Publications, originally published as Pragmatism. A New name for some old ways of thinking, New York, Longmans, Green and Company.

JENCKS C. (1991), The language of Post-Modern Architecture, London, Academy Editions [1977, New York, Rizzoli].

LATOUR B. (1988 [1984]), The Pasteurization of France, Cambridge, Mass. and London, England, Harvard University Press (translated from French by John Law and Alan Sheridan).

LATOUR B.\& HERMANT É. (1998), Paris Ville Invisible, Paris, Les Empêcheurs de penser en rond \& La Découverte.

LATOUR B. (2004), "Why has Critique Run out of Steam : From Matters of Fact to Matters of Concern”, Critical Inquiry, 30, 2, Winter 2004, pp. 225-248.

LATOUR B. (2004b), “Is There a Non-Modern Style ?”, Domus, January 2004. 
LATOUR B. (2004c), Politics of Nature: How to Bring the Sciences into Democracy, Cambridge and London, Harvard University Press.

LATOUR B. (2005), Re-assembling the Social : An Introduction to Actor-Network-Theory, Oxford University Press.

LATOUR B. \& YANEVA A. (2009), “Give me a Gun and I Will make All Buildings Move : an ANT's View of Architecture", in Explorations in Architecture : Teaching, Design, Research, Basel, Birkhauser, pp. 80-89.

LAW J. \& MOL A. (2005) "Boundary Variations", Guest Editorial, Environment and Planning D. Society and Space, 23, pp. 637-642.

MENAND L. (1997), “An introduction to Pragmatism”, in Pragmatism, A Reader, ed. Vintage.

MOULAERT F., RODRIGUEZ A., SWYNGEDOUW E. (eds.) (2003), The Globalised City - Economic Restructuring and Social Polarisation in European Cities, New York, Oxford University Press.

MOL A. \& DE LAET M. (2000), “The Zimbabwe Bush Pump : Mechanics of a Fluid Technology”, Social Studies of Science, 30, 2, pp. 225-263.

SERRES M. (1982), “Theory of the quasi-object”, in The Parasite, Baltimore, Johns Hopkins University Press.

SMITH N. (1996), The New Urban Frontier : Gentrification and the Revanchist City, Routledge .

STENGERS I. (2000), Réinventer la ville, le choix de la complexité, Préface d'Alain Berestetsky et Thierry Kübler. Edité à l'occasion d"'Urbanités", rencontres pour réinventer la ville, une initiative du Département de la Seine Saint-Denis organisée par la Fondation 93 dans le cadre de citésplanète, réalisée en collaboration avec l'ASTS. Last accessed 24 November 2010 http:// www.onoci.com /fonda_signaletique/pdf/urbanit \%E9s/isabelle_stengers.pdf.

STENGERS I. (2002), “A ‘Cosmo-Politics' - Risk, Hope, Change. A conversation with Isabelle Stengers”, in ZOURNAZIE M., Hope : New Philosophies for Change, Australia, Pluto Press, pp. 244-272. STENGERS I. (2005), “The Cosmopolitical Proposal”, in LATOUR B. \& WEIBELP. (eds.), Making Things Public - Atmospheres of Democracy, ZKM and The MIT Press, pp. 994-1003.

STENGERS I. (2005b), "Introductory notes on an ecology of practices", Cultural Studies Review, 11, 1, March 2005, pp. 183-196.

TILL J. (2006), The architect and the Other, http://www.opendemocracy.net/ ecology-landscape/ architecture_3680.jsp [last accessed 31 May 2011].

YANEVA A. (2009), The Making of a Building : A Pragmatist Approach to Architecture, Peter Lang.

YANEVA A. (2009b), Made by the Office for Metropolitan Architecture : An Ethnography of Design, 010 Publishers.

\section{NOTES}

1. Such typical example of a complex society - an example Stengers takes from Bruno Latour - is a group of Babouins (Stengers, 2000).

2. Also in reference to the "The loyalties of knowledge" research projects involving amongst others Serge Gutwirth, Isabelle Stengers, and Bruno Latour, which is dedicated to the study of imbroglios of knowledge, institutions, actants and things. 
3. See in particular : Latour and Yaneva's "object-in-flight"' (2009) and Mol and De Laet's "fluid object" (2005).

4. According to Till, "architects cling to a perfected model of practice, neatly and simplistically summarised in an idealised version of the Vitruvian triad - commodity, firmness and delight" (Till, 2009).

5. Paris emerges from the composition of the multiple Parises. For example, the Pont Neuf is not a fix, freestanding object but is "held together" by numerous networks and agencies (Latour and Hermant, 1998).

6. For example: Latour's columns in architecture magazine Domus, throughout 2004 ; Yaneva, 2009, 2009b ; Houdaert and Minato, 2009.

7. See Cairns (2009), Footprint Journal, issue 4 (Doucet and Cupers, 2009), Spatial Agency group, Sheffield; AHRA (Architectural Humanities Research Association) conference 2009.

8. "Building for Brussels. Architecture and Urban Transformation in Europe", 9 October28 November 2010, Centre of Fine Arts in Brussels, curated by Joachim Declerck and the Architecture Workroom Brussels, on the occasion of the Belgian presidency of the European Union.

9. E.g. Brenner and Theodore, 2002 ; Moulaert, Rodriguez, and Swyngedouw, 2003 ; Smith, 1996.

10. See the intellectual work and activism of the Archives d'Architecture Moderne and ARAU.

11. I don't count the Large-scale Urban Development schemes of the European Quarter and the Gare du Midi (Eurostation) for these have only delivered an endless repetition of architecture promoteure rather than the star architecture that would accompany such schemes in many other cities.

12. It is argued, in particular by Hans Ibelings, that, in comparison to cities with significant amounts of architectural highlights, in Brussels, iconic architecture is today still able to have significant effects.

13. Joachim Declerck, http://www.youtube.com/watch?v=iddMd5tDYP0 (author's translation from Dutch).

14. Perhaps most explicitly by Pascal Smet: "one city, one region ; one city, one mayor, like everywhere else ; one city, one future”, États Généraux, 25 April 2008.

15. For example, in 2003, it supported the actions around the European Parliament (Gare de Luxembourg); in 2004, it reinforced the actions already taking place at the RAC site (MAPRAC).

16. On the Rijks Administratief Centrum Site (RAC), a gigantic, state-owned, office complex that had been questionably resold to private owners.

17. For more details on the working of Citymined as a "learning" laboratory, see Doucet, 2008.

18. Parckdesign is initiated by the public administration Institut Bruxellois pour la Gestion de l'Environnement (IBGE)/ Brussels Instituut voor Milieubeheer (BIM), in collaboration with Recyclart.

19. Such as the City Salon (stadssalon), organised for the design of the Bruegelplein ; and the Square Ursulines project (including a skatepark) as a collaboration of young architecture graduates, skaters, and the established architecture office L'Escaut. 
20. This is what Stengers called the difference between unity and convergence (Stengers, 2002).

\section{ABSTRACTS}

Informed by object-oriented and relational perspectives on space, this article argues for more complex accounts of architectural and urban problématiques. Starting from Isabelle Stengers' distinction between la ville complexe and la ville compliquée, it discusses the 2010 exhibition "Building for Brussels. Architecture and Urban Transformation in Europe" (BOZAR, Centre of Fine Arts Brussels) as a showcase of how architects struggle to adopt a "complex" and "irreductive" approach. This article, as such, uses the discussion of this exhibition as a device to explore the methodological consequences of a relational approach to the city, namely the simultaneous need for more complex accounts of objects (e.g. a city, a building) and an appropriate modus operandi for making such accounts. It argues that, instead of choosing for complexity, the "Building for Brussels" exhibition has made the choix de la complication, and this largely because of a strong disciplinary belief in the all-encompassing force of architecture to "solve" the city.

Zich baserend op objectgeoriënteerde en relationele perspectieven op de ruimte, verdedigt dit artikel meer complexe lezingen van architecturale en stedelijke problématiques. Dit artikel analyseert, vertrekkend van Isabelle Stengers' onderscheid tussen la ville complexe en la ville compliquée, de 2010 tentoonstelling "Building for Brussels. Architecture and Urban Transformation in Europe" (BOZAR) en beschouwt het als een typisch voorbeeld van hoe architecten worstelen om een meer complexe en irreductieve houding aan te nemen vis-à-vis ruimtelijke vraagstukken. Als dusdanig wordt de discussie van deze tentoonstelling aangewend om de methodologische consequenties van een relationele kijk op de stad te onderzoeken: namelijk de nood aan een complexere lezing van objecten (een stad, een gebouw) alsook een gepaste modus operandi voor zulke complexe lezingen. Dit artikel argumenteert dat de "Building for Brussels" tentoonstelling, in plaats van te kiezen voor complexiteit, opteerde voor de choix de la complication, en dat dit grotendeels toe te wijzen is aan een sterk disciplinair geloof in de alomvattende kracht van de architectuur om de stad 'op te lossen'.

\section{INDEX}

Keywords: Brussels, relational perspectives on space, irreduction, architecture, Isabelle Stengers, choix de la complexité

Trefwoorden Brussel, relationele perspectieven op de ruimte, irreductie, architectuur, Isabelle Stengers, choix de la complexité 


\section{AUTHOR}

\section{ISABELLE DOUCET}

School of Environment and Development/Manchester Architecture, Research Centre, University of Manchester, isabelle.doucet@manchester.ac.uk 